\title{
Ethanolic Extract of Papaya Leaves (Carica papaya) and its Fractions have no Potential Cytotoxicity on T47D Cells
}

\author{
Ratna Yuliani*, Faisal Syahdeni \\ Faculty of Pharmacy, Universitas Muhammadiyah Surakarta \\ Jl. A Yani Tromol Pos 1, Pabelan, Kartasura, Surakarta, Indonesia \\ *E-mail: ratna.yuliani@ums.ac.id
}

Received: 27 April 2020; Accepted: 22 Juni 2020; Published: 29 Juni 2020

\begin{abstract}
Breast cancer is one type of cancer that causes high mortality rate in women. Plants produce secondary metabolites with a wide range of activity, one of which is as an anticancer. This research was conducted to investigate the cytotoxic effect of ethanolic extract of papaya leaves (Carica papaya) and its fractions on T47D cell line. Extraction of the natural compounds from papaya leaves was carried out by soaking the leaf powder in $96 \%$ ethanol followed by filtration and solvent evaporation. Liquid partition was done to obtain hexane, ethyl acetate, and water fractions. The cytotoxicity of the extract and the fractions was tested using MTT assay. Identification of chemical compounds in the ethyl acetate fraction was conducted using a thin layer chromatography method that used silica gel GF 254 as the stationary phase and acetone and hexane (4:6) as the mobile phase. The MTT assay result shows that the extract does not inhibit the growth of T47D cells. The viability of T47D cells can be reduced by the hexane, ethyl acetate, and water fractions with IC $_{50}$ values of 2,231.30, 557.33, and 2,112.81 $\mu \mathrm{g} / \mathrm{mL}$, respectively. The ethyl acetate fraction contains flavonoids, alkaloids, phenolics, and terpenoids. The ethanolic extract of papaya leaves and the fractions has no potential cytotoxicity on T47D cells due to high $I_{50}$ values.
\end{abstract}

Keywords: cytotoxic, extract, papaya, MTT, T47D

\section{INTRODUCTION}

Cancer is characterised by uncontrollable of cell division. This abnormality may lead to the spread of cancerous cells to other parts of the body (O'Donnell-Tormey and Tontonoz, 2016). In 2018, the estimated prevalent and incident of breast cancer in females worldwide were 6,875,099 (IARC, 2020a) and 2,088,849 cases (IARC, 2020b), respectively. In addition, the number of deaths in women caused by cancer in 2018 worldwide was 626,696 . The number shows the highest mortality because of cancer in women (IARC, 2019). In 2018, 333,269 women died because of breast cancer in Indonesia (IARC, 2020c).

Cancer treatments usually involve surgery, radiation, chemotherapy, and endocrine therapy. The treatments cause several side effects such as diarrhoea, nausea, vomiting, fatigue, fever, alopecia, and leukopenia (Alldredge et al., 2013). Therefore, a new approach to reduce the side effects and improve tolerance of the chemotherapy is needed (Nurgali et al., 2018). Exploration of secondary metabolites from plants is one way to screen active compounds as new anticancer agents that have minimum side effects. One plant that produces many secondary metabolites with a wide range of activity is papaya (Carica papaya) (Priyadarshi and Ram, 2018)

Cytotoxic activity of papaya leaves has been tested on several cells. Methanolic extract of papaya leaves that contains saponins, triterpenoids, flavonoids, and glycosides has cytotoxicity on LLC-MK2 cells. However, chloroform extract that contains alkaloids, tannins, and phenolics has no cytotoxic effect on the same cells (Joseph et al., 2014). Papaya leaf extract has cytotoxic activity on non-cancerous human keratinocyte cells (HaCaT) and squamous cell carcinoma (SCC) 25 (Nguyen et al., 2015). Kurniasari et al. (n.d) also demonstrated that ethanol and ethyl acetate fractions of ethanolic extract of papaya leaves reduce the viability of MCF-7 cells. 
This research aimed to investigate the cytotoxicity of ethanolic extract of papaya leaves and its fractions on T47D cells and determine the phytoconstituents present in the ethyl acetate fraction.

\section{RESEARCH METHODOLOGY Extraction and fractionation}

Approximately 174.4 grams of papaya leaf powder were soaked in $1.22 \mathrm{~L}$ of $96 \%$ ethanol for 3 days with occasional stirring. Macerate was filtered using a vacuum Buchner funnel and the solvent was evaporated using a rotary evaporator (Heidolph) and water bath (Memmert) at $60^{\circ} \mathrm{C}$. Seven grams of the extract were dissolved in a mixture of $70 \mathrm{~mL}$ of distilled water and $17.5 \mathrm{~mL}$ of ethanol. The extract solution was poured into a separatory funnel and $87.5 \mathrm{~mL}$ of hexane was added. The funnel was shaken and let stand at room temperature until 2 layers formed. The hexane fraction was separated from the water fraction then the water fraction was poured back to the separatory funnel and $87.5 \mathrm{~mL}$ of hexane was added. Fractionation was carried out as previous steps until the hexane layer was clear which means no compounds left to be extracted by the solvent. The fractionation was continued by pouring the water fraction into the separatory funnel and $87.5 \mathrm{~mL}$ of ethyl acetate was added. The fractionation was done with the same steps as fractionation using hexane. Finally, the water, ethyl acetate, and hexane fractions were evaporated using a rotary evaporator and water bath at $60^{\circ} \mathrm{C}$.

\section{Cytotoxic activity test}

The cytotoxicity of the extract and its fractions on T47D cells was tested using MTT assay. The cell line was obtained from the Mammalian Cell Culture Laboratory of the Faculty of Pharmacy, Universitas Muhammadiyah Surakarta, where the research was carried out. The T47D cells with density of $10^{4}$ cells/well were plated into a 96well plate. An inverted microscope (Olympus) was used to observed the cell distribution. The cells were incubated in a
$\mathrm{CO}_{2}$ incubator (Binder) at $37^{\circ} \mathrm{C}$ until the cells adhere to the bottom of the wells. After the incubation, the Roswell Park Memorial Institute (RPMI) media was discarded. Phosphate-buffered saline with volume of $100 \mu \mathrm{L}$ was used to wash the cells then the extract and fractions with the concentration of $200,400,800$, and $1600 \mu \mathrm{g} / \mathrm{mL}$ were added to the wells. Dimethyl sulfoxide (DMSO) with the percentage of $1.6 \%$ was added to the other wells as solvent controls. Doxorubicin, the positive control, with the concentrations of $0.0625,0.125,0.25$ and $0.5 \mu \mathrm{g} / \mathrm{mL}$ were loaded into the other wells. The plate was then incubated for 24 hours at $37^{\circ} \mathrm{C}$ in a $\mathrm{CO}_{2}$ incubator. Following the incubation, media in the wells were aspirated and the phosphatebuffered saline was added to the wells to wash the cells. MTT reagent which had been diluted in media to reach concentration of 0.5 $\mathrm{mg} / \mathrm{mL}$ was added into all wells with the volume of $100 \mu \mathrm{L}$. The plate was incubated for 2 hours at $37^{\circ} \mathrm{C}$. After the incubation, the cells were observed under an inverted microscope to check the formation of formazan. Stopper reagent (10\% sodium dodecyl sulphate in $0.01 \mathrm{~N} \mathrm{HCl}$ ) with volume of $100 \mu \mathrm{L}$ was added into the wells to dissolve the formazan. Next, the plate was wrapped using paper and incubated at room temperature overnight. A plate reader (BioTek) was used to read the absorbance in each well at wavelength of $550 \mathrm{~nm}$. In this study, the absorbance of the solvent control was lower than the cell control thus the following formula was used to calculate the percentage of viable cells.

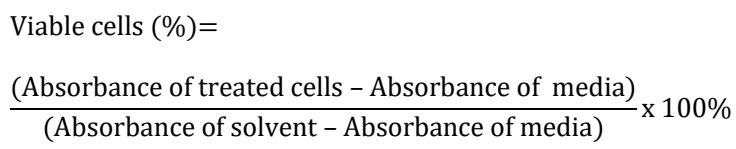

The $\mathrm{IC}_{50}$ values are determined from the equation of linear regression between the log concentration and the percentage of viable cells (Putri, 2013). 
Table 1. Cytotoxicity of the ethanolic extract of papaya leaves, its fractions, and doxorubicin on T47D cells

\begin{tabular}{|c|c|c|c|}
\hline Tested materials & $\begin{array}{l}\text { Concentration } \\
(\mu \mathrm{g} / \mathrm{mL})\end{array}$ & $\begin{array}{l}\text { Average of viable } \\
\text { cells }(\%)\end{array}$ & $\mathrm{IC}_{50}(\mu \mathrm{g} / \mathrm{mL})$ \\
\hline \multirow[t]{4}{*}{ Extract } & 200 & 105.51 & - \\
\hline & 400 & 94.31 & \\
\hline & 800 & 112.33 & \\
\hline & 1600 & 60.53 & \\
\hline \multirow[t]{4}{*}{ Hexane fraction } & 200 & 122.77 & $2,231.30$ \\
\hline & 400 & 107.40 & \\
\hline & 800 & 114.04 & \\
\hline & 1600 & 42.12 & \\
\hline \multirow{3}{*}{$\begin{array}{l}\text { Ethyl acetate } \\
\text { fraction }\end{array}$} & 200 & 114.99 & 557.33 \\
\hline & 400 & 91.46 & \\
\hline & 800 & 15.18 & \\
\hline \multirow[t]{4}{*}{ Water fraction } & 200 & 112.90 & $2,112.81$ \\
\hline & 400 & 104.74 & \\
\hline & 800 & 97.72 & \\
\hline & 1600 & 44.97 & \\
\hline \multirow[t]{4}{*}{ Doxorubicin } & 0.0625 & 93.55 & 0.15 \\
\hline & 0.125 & 50.10 & \\
\hline & 0.25 & 13.67 & \\
\hline & 0.5 & 12.90 & \\
\hline
\end{tabular}

\section{Thin layer chromatography (TLC)}

Natural compounds present in the ethyl acetate fraction were identified using TLC method. Ten milligrams of the fraction were dissolved in ethyl acetate with the final volume of $100 \mu \mathrm{L}$. The solution was spotted onto silica gel plates followed by development using a mixture of acetone and hexane (4:6). Spots on the plate were detected under visible light, $254 \mathrm{~nm}$-UV light, and 366 nm-UV light. The spots were then visualised by spraying the spots with anisaldehydesulphuric acid, Dragendorff, and $\mathrm{FeCl}_{3}$ to detect terpenoids, alkaloids, and phenolics, respectively. The spots were also exposed to ammonia vapour to identify flavonoid compounds.

\section{RESULT AND DISCUSSION}

The results of the MTT assay of the ethanolic extract of papaya leaves and the fractions on T47D cells show different cytotoxic activity between the extract and the fractions. As shown in Table 1, the extract with concentration of up to $1600 \mu \mathrm{g} / \mathrm{mL}$ is unable to inhibit $50 \%$ population of T47D cells thus the $\mathrm{IC}_{50}$ value of the extract cannot be determined. On the other hand, hexane and water fractions are able to reduce the cell population with $\mathrm{IC}_{50}$ values of above $2000 \mu \mathrm{g} / \mathrm{mL}$ whereas the ethyl acetate fraction has the lowest $\mathrm{IC}_{50}$ values of $557.33 \mu \mathrm{g} / \mathrm{mL}$. The results show that the extract has the lowest activity compared to the fractions. It seems that the fractionation affects the cytotoxic effect of the fractions. The ethanolic extract of papaya leaves may contain more compounds than the fractions but not all of the compounds toxic to the cells. Therefore, the concentration of the active compounds in the extract may be low thus the activity of the extract is weaker than the fractions. On the other hand, fractions contain lesser compounds than the extract but the concentration of the active compounds may be higher than the extract. During the fractionation, compounds in the extract were grouped based on the polarity of the 
compounds. Hexane, ethyl acetate, and water fractions may contain nonpolar, semi polar, and polar compounds, respectively. It means that only certain group of compounds are present in each fraction which is different from the ethanolic extract that contains compounds with different polarity. In this study, the ethyl acetate fraction has the lowest $\mathrm{IC}_{50}$ value which indicates that the fraction has the highest cytotoxic activity. It appears that the toxic compounds may accumulate in the ethyl acetate fraction. The $\mathrm{IC}_{50}$ value of doxorubicin as positive control is $0.15 \mu \mathrm{g} / \mathrm{mL}$. It shows that the positive control has strong cytotoxic activity.

The $\mathrm{IC}_{50}$ value reflects the cytotoxicity of the materials tested. Lower $\mathrm{IC}_{50}$ value indicates higher cytotoxic activity. According to the National Cancer Institute (United States of America), crude extracts that have $\mathrm{IC}_{50}$ values of $<20 \mu \mathrm{g} / \mathrm{mL}$ can be considered to have strong cytotoxic activity (Vijayarathna and Sasidharan, 2012). The ethanolic extract of papaya leaves and the fractions have both IC $_{50}$ values of $>20 \mu \mathrm{g} / \mathrm{mL}$. It means that the ethanolic extract of papaya leaves and the fractions possess no potential cytotoxic activity on T47D cells.

The cytotoxic activity of papaya leaves has been tested on several cancer cell lines. Ethanolic extract of papaya leaves with the concentration of $250 \mu \mathrm{g} / \mathrm{mL}$ inhibits the MCF-7 and T47D growth with percentage of $8.43 \%$ and $9.77 \%$, respectively (Hariyanti, 2018). The results demonstrate that the extract has no cytotoxicity on the breast cancer cells. The findings are in agreement with this study which shows that the ethanolic extract of papaya leaves does not toxic to T47D cells. On the other hand, ethanolic extract of papaya leaves with concentration of $9.73 \mu \mathrm{g} / \mathrm{mL}$ decreases $50 \%$ of viable MCF-7 cells (Amalia, 2016). In addition, acidic ethanolic extract of papaya leaves shows cytotoxicity on SCC25 cells with $\mathrm{IC}_{50}$ value of 77.18 $\mu \mathrm{g} / \mathrm{mL}$ while the $\mathrm{IC}_{50}$ value of the extract on $\mathrm{HaCaT}$ cells is $199.5 \mu \mathrm{g} / \mathrm{mL}$ (Nguyen et al., 2015). Moreover, ethanol and ethyl acetate fractions from ethanolic extract of papaya leaves show potential cytotoxicity on MCF-7 cells with $\mathrm{IC}_{50}$ values of 12.1338 and 11.4156 $\mu \mathrm{g} / \mathrm{mL}$, respectively (Kurniasari et al., n.d). The ethyl acetate fraction has much higher cytotoxic activity on MCF-7 cells than that of on T47D cell in this study. The differences in the research findings possibly due to the differences in the cell lines used. Rashed and Fouche (2013) proved that different cancer cells respond differently to the same extract of papaya aerial parts.

Thin layer chromatography was conducted to identify chemical compounds in the ethyl acetate fraction with the highest cytotoxic activity. Several spray reagents such as Dragendorff, $\mathrm{FeCl}_{3}$, anisaldehydesulphuric acid, and ammonia vapour were used to identify group compounds of alkaloids, phenolics, terpenoids, and flavonoids, respectively. Figure 1 shows several spots that quench the fluorescence of the plate when the spots were observed under UV light at wavelength of $254 \mathrm{~nm}$. It means that the fraction contains compounds that have at least two conjugated double bonds (Wagner and Bladt, 2001). Observations under $366 \mathrm{~nm}-\mathrm{UV}$ light without chemical treatment depict several spots with blue and red fluorescence. Exposure of the spots to ammonia and chemical reagents changes the colour of several spots. The spots that were exposed to ammonia vapour show colour change to bright yellow. It indicates that flavonoids may present in the ethyl acetate fraction. Dragendorff spray changed the colour of the spots to brown that shows the existence of alkaloids in the fraction. Greycolored spots were detected after $\mathrm{FeCl}_{3}$ spraying that reveals the presence of phenolics. Pink and violet colour that develop after anisaldehyde-sulphuric acid spraying show that the ethyl acetate fraction contains terpenoids. It appears that the ethyl acetate fraction of ethanolic extract of papaya leaves contains flavonoids, alkaloids, phenolics, and 


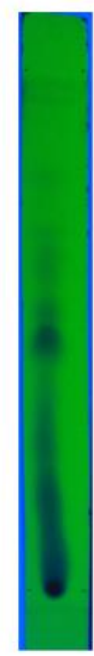

A

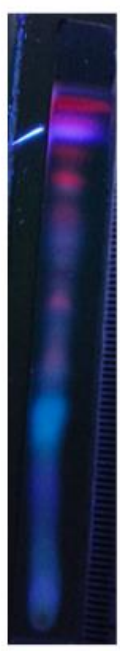

B

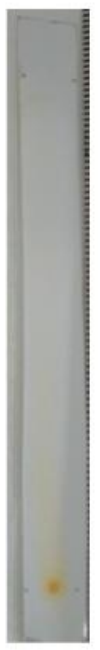

C

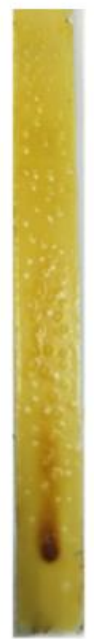

D

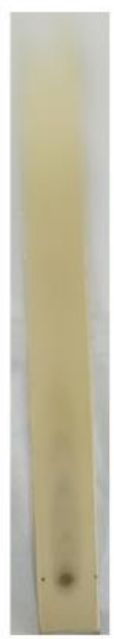

$\mathbf{E}$

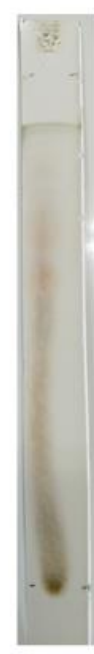

$\mathbf{F}$

Figure 1. Thin layer chromatography results of the ethyl acetate fraction of papaya leaves. Silica gel GF 254 was used as a stationary phase and mixture of aceton and hexane (4:6) as a mobile phase. A.

Observation under UV $254 \mathrm{~nm}$ without spray reagent, B. Observation under UV $366 \mathrm{~nm}$ without spray reagent, $C$. Observation under visible light after ammonia vapour exposure, D. Observation under visible light after Dragendorff spray, E. Observation under visible light after $\mathrm{FeCl}_{3}$ spray, F. Observation under visible light after anisaldehyde-sulphuric acid spray.

terpenoids. However, this study did not further elucidate the structure of the compounds thus the exact compounds of the secondary metabolites could not be determined.

The chemical structures of the natural compounds in papaya leaves have been elucidated in other researches. Papaya leaves contain alkaloids i.e. pseudocarpaine, dehydrocarpaine I, carpaine, and dehydrocarpaine II (Patil et al., 2014). The research finding supports the TLC results of this study that show alkaloids in the ethyl acetate fraction. In this study, phenolic compounds are detected in the fraction. This result is similar with research finding reported by Patil et al. (2014) who found that papaya leaves contains the same group of compounds such as p-coumaric acid, caffeic acid, protocatechuic acid, quercetin, 5,7 dimethoxycumarin, and kaempferol chlorogenic acid. El Azim et al. (2014) also identify phenolic compounds in the methanolic extract of papaya leaves such as protocatechuic acid, p-cumaric acid, chlorogenic acid, and caffeic acid. The presence of flavonoid in papaya leaves has been proven by Nugroho et al. (2017) who isolated and identified 7 flavonoids from papaya leaves such as kaempferol, kaempferol 3-( $2^{\mathrm{G}}$-rhamnosylrutinoside), kaempferol 3-rutinoside, quercetin, quercetin 3-rutinoside, myricetin 3-rhamnoside, dan quercetin 3-( $2^{\mathrm{G}}$-rhamnosylrutinoside $)$ The finding of terpenoids in ethanolic extract of papaya leaves by Sushmita et al. (2018) supports the results of TLC in this research that prove the presence of terpenoids in the ethyl acetate fraction of the ethanolic extract of papaya leaves. In this study, despite the detection of alkaloids, flavonoids, terpenoids, an phenolics in the ethyl acetate fraction, the fraction has no potential cytotoxic activity on T47D cells.

\section{CONCLUSIONS}

The ethanolic extract of papaya leaves and the fractions do not have cytotoxic effect on breast cancer cells, T47D. 


\section{References}

Alldredge, B.K., Corelli, R.L., Ernst, M.E., Guglielmo, B.J., Jacobson, P.A., Kradjan, W.A., dan Williams, B.R., 2013. Applied Therapeutics: The Clinical Use of Drugs, Tenth edition, Lippincott Williams \& Wilkins: Philadelphia.

Amalia, P.K., 2016. Uji aktivitas sitotoksik ekstrak etanol daun keladi tikus (Typonium flagelliforme L.), kemangi (Ocimum sanctum L.), dan pepaya (Carica papaya L.) terhadap sel MCF-7, Naskah Publikasi, Fakultas Farmasi, Universitas Muhammadiyah Surakarta.

El Azim, M.H.M.A., El-Mesallamy, A.M.D., Hussein, S.A.M., dan El-Gerby, M., 2014. Phenolic composition and biological activities of methanolic extract of Carica papaya, Natural Product: An Indian Journal, 10(5), pp. 163-170.

Hariyanti, S., 2018. Uji sitotoksik ekstrak etanol daun pepaya (Carica papaya) terhadap sel MCF7 dan sel T47D. Naskah Publikasi, Fakultas Farmasi, Universitas Muhammadiyah Surakarta.

International Agency for Research on Cancer, 2019. Estimated number of death in 2018, worldwide, all cancers, females, all ages, available online: http://gco.iarc.fr/today/ [12 April 2019].

International Agency for Research on Cancer, 2020a. Estimated number of prevalent cases (5year) in 2018, worldwide, all cancer, all ages, available online: http://gco.iarc.fr/today/ [5 March 2020].

International Agency for Research on Cancer, 2020b. Estimated number of new cases in 2018, worldwide, all cancers, females, all ages, available online: http://gco.iarc.fr/today/ [5 March 2020].

International Agency for Research on Cancer, 2020c. Estimated number of death in 2018, Asia, Indonesia, all cancers, females, all ages, available online: http://gco.iarc.fr/today/ [5 March 2020].

Kurniasari, D., Kusmardi, and Sunaryo, H., n.d. Uji sitotoksik fraksi etil asetat dan fraksi etanol ekstrak etanol daun pepaya (Carica papaya L.) terhadap sel kanker payudara MCF-7.

Joseph, B., Sankarganesh, P., Ichiyama, K., and Yamamoto, N., 2014. In vitro study on cytotoxic effect and anti-DENV2 activity of Carica papaya L. leaf., Frontiers in Life Science, 8(1), pp.18-22.

Nguyen, T.T., Parat, M-O, Hodson, M.P., Pan, J., Shaw, P.N., Hewavitharana, A.K., 2015. Chemical characterization and in vitro cytotoxicity on squamous cell carcinoma cells of Carica papaya leaf extracts, Toxins, 8(7), pp. 1-11.

Nugroho, A., Heryani, H., Choi, J.S., and Park, H-J., 2017. Identification and quantification of flavonoids in Carica papaya leaf and peroxynitrile-scavenging activity, Asian Pacific Journal of Tropical Biomedicine, 7 (3), 208-213.

Nurgali, K., Jagoe, R.T., and Abalo, R., 2018. Adverse effects of cancer chemotherapy: anything new to improve tolerance and reduce sequelae?, Frontiers in Pharmacology, 9(245), pp. 1-3. 
O'Donnel-Tormey, J. and Tontonoz, M., 2016. Cancer and The Immune System: The Vital Connection, Cancer Research Institute.

Patil, T., Patil, S., Patil, A., and Patil, S., 2014. Carica papaya leaf extracts-an ethnomedicinal boon, International Journal of Pharmacognosy and Phytochemical Research, 6(20), pp. 260265.

Putri, H., 2013. Protokol: uji sitotoksik metode MTT, Cancer Chemoprevention Research Center, Fakultas Farmasi, UGM.

Priyadarshi, A. and Ram, B., 2018. A review on pharmacognosy, phytochemistry and pharmacological activity of Carica papaya (Linn.) leaf, International Journal of Pharmaceutical Sciences and Research, 9(10), pp. 4071-4078.

Rashed, K.N. and Fouche, G., 2013. Anticancer activity of Carica papaya extracts in vito and phytochemical analysis, Greener Journal of Pharmacy and Pharmacology, 1(1), pp. 001-005.

Sushmita, H.S., Rajesh, V., Madappa, M.B, and Sathyamurthy, B., 2018. A comparative study on characterisation of various extracts of Carica papaya leaves, European Journal of Pharmaceutical and Medical Research, 5(6), pp. 401-407.

Vijayarathna, S. and Sasidharan, S., 2012. Cytotoxicity of methanol extracts of Elaeis guineensis on MCF-7 and vero cell lines, Asian Pasific Journal of Tropical Biomedicine, 2(10), pp. 826829.

Wagner, H. and Bladt, S., 2001. Plant drug analysis. A thin layer chromatography atlas, second edition. Berlin: Springer. 